\title{
Presídlenie a vývoj etnickej štruktúry obyvatel'stva na juhu \\ Slovenska v rokoch 1945 - 1948 (na príklade konkrétnych obcí)
}

\author{
Resettlement and development of ethnic structure of the \\ population in the south of Slovakia, $1945-1948$ \\ (on the example of concrete municipalities)
}

\section{Zlatica Sáposová, Miroslava Gallová}

https://doi.org/10.33542/VSS2021-2-05

\begin{abstract}
After the Second World War, the Czechoslovak Republic actively participated in migratory movements taking place in Central and Eastern Europe in order to get rid of the two most numerous ethnic groups - Hungarian and German. In order to fulfil its ideas, it used forced relocation, the exchange of population on the basis of an agreement, as well as the internal relocation of the population. The mechanical movement of the population on the territory of Slovakia took place intensively in the southern regions inhabited by the inhabitants of Hungarian nationality. The migration (resettlement, relocation) of the population was able to break the unified ethnic character of southern Slovakia and create ethnically mixed areas. This paper focuses on the means used by Czechoslovakia to reduce the population of Hungarian nationality. We chose municipalities in which various forms of migration appeared, while in each of the selected municipalities a different form of resettlement was dominant and at the same time we monitored its impact on the ethnic structure of the municipality. In the individual municipalities surveyed, based on censuses, there was no radical change in ethnic structure (even in the long term), despite the fact that the number of immigrants was considerable.
\end{abstract}

Keywords: population exchange, resettlement, migration, ethnic structure, nationality issue

\section{Úvod}

Po druhej svetovej vojne migračný pohyb prebiehajúci v strednej a juhovýchodnej Európe (približne 10 miliónov l'udí bolo nútených - sčasti aj dobrovol'ne - opustit' svoju rodnú krajinu a presídlit' sa na územie iného štátu) súvisel najmä so zmenami štátnych hraníc s ciel'om vytvorenia národných štátov. Migrácia sa dotkla najmä nemeckých obyvatelov $v$ jednotlivých európskych krajinách: počet vyhnaných, utečencov z Pol'ska bol okolo $7-8$ miliónov, z Československa 2,6 - 3 milióny, z Mad’arska viac ako 200 tisíc. Z Juhoslávie sa 
odst’ahovalo viac ako 250 tisíc nemeckých obyvatel'ov, 150 tisíc bolo zavretých do pracovných táborov (z toho 60 tisíc osôb neprežilo). Tí, ktorí prežili, sa stali druhoradými štátnymi občanmi a na začiatku 50. rokov utiekli z krajiny alebo ich úrady „proste prehodili“ cez mad’arskú alebo rakúsku hranicu. Z Rumunska vysídlili 250 tisíc Nemcov. Obyvatel'ov s nemeckým pôvodom, nemeckým menom alebo menom nemecky znejúcim pozbierali do rumunských táborov a poslali ich do gulagu (90 \% zo 60 tisíc nevinných civilov sa už nikdy nevrátilo domov). Paralelne s vysídlením a vyhnaním Nemcov prebiehala značná migrácia pol'ských, ukrajinských, bieloruských a ruských obyvatelov. Až 520 tisíc obyvatel'ov s ukrajinskou, bieloruskou, ruskou a litovskou národnost'ou organizovane presídlili z Pol'ska na bývalé pol'ské územia pripojené k Sovietskemu zväzu, resp. do vnútorných regiónov Ukrajiny a Bieloruska. $Z$ bývalých regiónov východného Pol'ska, resp. z jednotlivých území Bieloruska a západnej časti Ukrajiny sa viac ako 1,5 milióna obyvatel'ov s pol'skou národnost'ou presídlilo do Pol'ska. Z pobaltských štátov deportovali 300 - 350 tisíc obyvatel'ov (najmä inteligenciu) do vnútrozemia Sovietskeho zväzu, namiesto nich prist'ahovali (do východného Pruska a na západné pohraničné územia získané od Pol'ska) približne 2,5 milióna ruských kolonistov (osadníkov). $\mathrm{Na}$ juhu Európy (na Balkáne) tiež prebiehal presun obyvatelov. 120 tisíc vysídlených Bulharov (z Trácie a gréckeho Macedónska) sa vrátilo v rokoch 1944 - 1945 naspät' do starej vlasti a 100 - 150 tisíc bulharských Turkov prinútili medzi rokmi 1949 a 1951 „dobrovol'ne“ sa prest'ahovat' do Turecka. (Romsics 2000, s. 13-14)

Neoddelitel'nou súčast’ou európskeho migračného procesu po druhej svetovej vojne bola aj migrácia židovstva, ktoré prežilo holokaust. Presun židovského obyvatel'stva prebiehal dramaticky. Tí, ktorí prežili koncentračné tábory, sa bud' nemali kam vrátit' alebo sa vel'a z nich ani nechcelo vrátit' domov. Do Izraelského štátu (vnikol po 14. máji 1948) sa z Európy presídlilo 111 tisíc, a medzi rokmi 1948 až 1955 d’alších 342 tisíc židovských obyvatelov. (Romsics 2000 , s. 14) Na túto migráciu sa však dost' často zabúda.

Ciel'om predloženej práce je zobrazit' mechanický pohyb obyvatel'stva na juhu Slovenska, ktorý ovplyvnil vývoj etnickej štruktúry populácie. Nútené presídlenie, výmena obyvatel'stva, reslovakizácia mali za úlohu vytvorit' homogénny, z etnického hladiska jednotný štát, resp. národný štát. Prostriedky, ktoré boli použité proti mad'arskej národnosti spôsobili obrovskú stratu - migračné, asimilačné straty, obrovské majetkové škody, psychickú traumu. Predložená práca na konkrétnych obciach sleduje národnostné zloženie populácie pomocou údajov zo sčítaní obyvatel'stva. Zámerom bolo poukázat' na fakt, že existujú aj také mad’arské komunity, ktoré si dokázali zachovat' svoju väčšinovú pozíciu v národnostnej štruktúre obyvatel'stva. 


\section{Náčrt migračných pohybov}

V Európe sa $v$ minulosti nehovorilo o príčinách a dôsledkoch, resp. o neúspechu vysídl'ovania a výmeny obyvatel'ov $v$ dôsledku druhej svetovej vojny, a ani dodnes sa na túto problematiku nekladie dostatočný dôraz. Počas prvých mesiacov presunu obyvatel'stva sa ukázalo, že tieto mechanické pohyby nedosiahnu svoj ciel: nebolo možné riešit' etnickú otázku jednotlivých štátov presídlením obyvatel'stva, nedal sa zmenit' ich (multi)etnický charakter a urobit' z nich národné štáty. Hned' na začiatku daných migračných procesov (vyst'ahovanie, deportácie, výmeny obyvatel'stva - dobrovol'né či nútené) vyplávala na povrch aj ich nel'udskost'. Bolo jasné, že aplikácia princípu kolektívnej viny je neprípustná a ludsky nespravodlivá, pretože jednotlivca na základe (národnostného) pôvodu nemožno potrestat' za vinu vládnucej politickej elity.

Edvard Beneš po vytvorení exilovej štátnej reprezentácie v Londýne (1940) prevzal funkciu predsedu republiky a vyhlásil program obnovy Československej republiky s predmníchovskými hranicami. Znovu vytvorenú Československú republiku predstavil bez Nemcov a Mad'arov, ktorá bude štátom len Slovanov. Podla slov Vladimíra Clementisa bolo riešenie slovensko-mad'arského vzt'ahu možné dosiahnut' „jedine úplným likvidovaním mad’arskej menšiny u nás." (Šutaj 2013, s. 285)

Československá delegácia od mierovej konferencie v Paríži očakávala súhlas na jednostranný odsun obyvatel'ov mad’arskej národnosti. Získala síce súhlas na vysídlenie 3 miliónov obyvatel'ov nemeckej národnosti, ale spojenci nedovolili jednostranné vyst'ahovanie Mad'arov. Požiadavka československých politikov na jednostranné vysídlenie obyvatelov mad'arskej národnosti sa kvôli negatívnemu stanovisku vít’azných vel'mocí nedostala do mierovej zmluvy s Mad’arskom. Československá strana preto na riešenie mad’arskej otázky siahla na d'alšie prostriedky, ktoré boli obsahom „Presídlovacieho plánu Osídlovacieho úradu pre Slovensko“, ktorý zároveň bol aj bol súčast’ou dokumentu „Medzinárodné aspekty riešenia mad'arského problému“. (Šutaj 2013, s. 291) Dokument bol pripravený už tesne pred ukončením mierovej konferencie v Paríži. Za používané prostriedky boli považované: Dohoda o výmene obyvatel'stva, reslovakizačná akcia, vnútorné presídlovanie, konfiškačné normy, jednostranný transfer.

Československé úrady v roku 1945 na základe prezidentského dekrétu č. 88/1945 o všeobecné pracovní povinnosti začali obyvatel'ov mad'arskej národnosti násilne deportovat' na nútenú prácu do Čiech do uvol'nených miest po vysídlených Nemcoch. $V$ tom istom roku v jeseni bolo na nútené práce do Čiech odnesených približne 12 tisíc Mad’arov z južného Slovenska (inteligencia, úradníci, kvalifikovaní robotníci, remeselníci, pol'nohospodárski pracovníci...). (Simon 2004) Druhá etapa sa začala v lete 1947, ked’ vyhlásili kvôli nedostatku pracovnej sily $v$ českom pol'nohospodárstve "nábor“ medzi mad’arskými obyvatel'mi, resp. „rozsídl'ovanie“ obyvatel'stva mad’arskej národnosti na práce do Čiech. Dňa 17. novembra 
1946 československé orgány a vojenské jednotky začali deportovat' vybrané rodiny kvôli odmietnutiu návrhu jednostranného transferu mad’arskej národnosti mierovou konferenciou v Pariži. Počas deportácie presunuli 9610 rodín (41640 osôb). Akciu na presídlenie mad’arských obyvatel'ov vypracoval úrad Povereníctva vnútra a Slovenská presídlovacia komisia. (Vadkerty 1996, s. 55)

Deportácia zároveň slúžila ako nátlak na mad’arskú stranu, aby donútila mad’arskú vládu jednat' a začat' výmenu obyvatel'stva. Za československý úspech možno považovat' (aj ked' na nátlak Sovietskeho zväzu) podpísanie dohody o výmene obyvatel'stva s Mad'arskom dňa 27. februára 1946, v ktorej sa na základe vzájomnosti - reciprocity dohodli na počte presídlených obyvatel'ov. „Z hladiska československej politiky bola výmena obyvatel'stva považovaná za klúčové riešenie mad'arskej problematiky, od ktorého si slubovala zásadné zníženie počtu obyvatel'ov mad'arskej národnosti.“ (Šutaj 2013, s. 281)

Výmena obyvatel'stva nesplnila očakávanie československej strany, resp. nevyriešila mad'arskú otázku. Číselné údaje presídlencov uvádza slovenský historik Štefan Šutaj v počte 73273 osôb (Šutaj 1993, s. 139), mad’arský historik József Kugler 59774 osôb, a ten istý počet je udaný aj v konečnej správe o činnosti Československej presídlovacej komisie v súvislosti s výmenou obyvatel'stva medzi Československom a Mad'arskom. Samozrejme, že do úvahy treba brat' aj osoby prest’ahované pred účinnost'ou Dohody, podla § 16 Piešt'anského protokolu v počte 4340 a osoby, ktoré odišli podla rozhodnutia Zmiešanej komisie č. 47 v počte 7 783. To znamená, že z Mad'arska sa prest'ahovalo ešte okolo 12000 osôb mimo procesu presídlenia. (Sáposová 2019, s. 82) Za koniec výmeny obyvatel'stva medzi Československom a Mad'arskom sa považuje dátum 20. december 1948. Pritom výmena skutočne skončila po presídlení 150 rodín zo Slovenska do Mad'arska. Tieto rodiny nemali šancu na získanie československého štátneho občianstva. Výmena obyvatel'stva skončila až 5. januára 1949, dátum potvrdila aj Mad’arsko-československá zmiešaná komisia svojím konečným rozhodnutím č. 66, v ktorom výmenu obyvatel'stva vyhlásila za ukončenú. (Sáposová 2019, s. 88)

Zmenu $v$ etnickej štruktúre, presnejšie zmeny $v$ národnostnej štatistike chceli dosiahnut' „reslovakizačnou“ kampaňou v rokoch 1946 - 1947. Obyvatelia s mad'arskou národnost'ou, ktorí prijali slovenskú národnost' dostali naspät' stratené občianske právo, ich majetky neboli konfiškované a nedostali sa ani na zoznam deportovaných.

Pridelenie slovenskej národnosti žiadalo 410820 osôb, z toho 326679 osobám ho uznali, 84141 osobám žiadost' odmietli. Väčšina z tých, ktorým uznali slovenskú národnost', mala nad’alej mad'arskú identitu, mnoho z nich v 50. rokoch využilo možnost' a znova sa hlásili k mad’arskej národnosti. (Vadkerty 2004) Károly Kocsis hlavne na základe údajov sčitania obyvatelov predpokladal, že „reslovakizácia bude dlhšia - trvanlivejšia u 140000 prevažne v mestách už dlhšie žijúcich Mad’arov, resp. ich potomkov“. (Stark 2001, s. 403) 
Okrem spomenutých plánovaných akcií, ako bola deportácia, výmena obyvatel'stva, reslovakizácia, aj vnútorné presídlenie obyvatelov slúžilo ako prostriedok na rozbitie z etnického hl'adiska kompaktného územia južného Slovenska, ktoré patrilo medzi hlavné ciele slovenskej politiky pred vyhlásením Košického vládneho programu. Vnútorné presídlenie okrem národnostného aspektu malo aj sociálne pozadie. Chudobní, v zlých sociálnych podmienkach žijúci, nezamestnaní slovenskí osadníci - kolonisti mali byt' presídlení a mad'arské oblasti sa mali slovakizovat'. Okrem toho v južných obciach, mestách Slovenska mali umiestnit' slovenských repatriantov z Rumunska, Juhoslávie, Zakarpatskej Ukrajiny a v najväčšom počte z Mad’arska. (Szarka 2007, s. 419-420)

O optácii sa v rámci československo-sovietskych vzt'ahov uvažovalo prvýkrát v spojitosti s územím Zakarpatska: „[...] čo našlo svoj odraz aj v článku 2 Protokolu k Zmluve medzi ZSSR a ČSR o Zakarpatskej Ukrajine z 29. júna 1945. Podl'a neho, osoby slovenskej a českej národnosti, ktoré mali trvalé bydlisko na území Zakarpatskej Ukrajiny, mali právo, do 1. januára 1946, optovat' pre štátne občianstvo Československej republiky." (Gajdoš, Sjusko 1999, s. 28) Podla údajov, ktoré sú uvedené v oficiálnych československých dokumentoch, mal byt' počet prist'ahovalcov, ktorí prišli zo Zakarpatskej Ukrajiny na základe spomínaného protokolu, 5 377. Ako napísal Marián Gajdoš a Ivan Sjusko: „Nepochybujeme o správnosti týchto oficiálnych údajov, ktoré vychádzajú z podkladov opčnej komisie sídliacej v Užhorode. Rovnaké údaje sa nachádzajú aj v sovietskych oficiálnych zdrojoch. Prípady tzv. „neoficiálnej optácie vybavovanie opčných záležitosti mimo Užhorodu na československom území, falšovanie dokladov o štátnom občianstve a trvalom bydlisku, nelegálny prechod hranice atd', dovol'ujú vyslovit' presvedčenie, že skutočný počet optantov a občanov, ktorí odišli zo Zakarpatskej Ukrajiny v priebehu optácie s ciel'om získat' československé štátne občianstvo, sa podl'a našich odhadov pohyboval na úrovni 20000 l'udí, t. j. minimálne štyrikrát viac ako to vyplýva z oficiálnych zdrojov." (Gajdoš, Sjusko 1999, s. 32-33)

„Podl'a prezidentského dekrétu 27/1945 je vnútorná kolonizácia „nenásilným, politicky motivovaným procesom, ktorý má za následok demografické zmeny“. Tvorcovia presídlenia sever-juh neskôr severovýchod-juhozápad na Slovensku sledovali tri ciele. Zabezpečenie „záujmov slovenského národa v oblasti obývanej Mad’armi“, zabezpečenie „blahobytu, teda obohatenia“ slovenského národa, a posunutie slovenskej etnickej hranice až k Dunajskej čiare. Podla toho sa autori vnútorného presídlenia postarali o to, aby sa „slovenský prvok“ stal väčšinou v československo-mad'arskom pohraničí." (Vadkerty 2014, s. 8)

Katalin Vadkerty na základe výkazu vnútorných presídlení zo dňa 11. decembra 1948 sumarizovala výsledky vnútorných presídlení obyvatel'ov v rokoch 1945 - 1948. (Vadkerty 2014, s. 10) 5011 slovenských rodín, spolu 23027 ludí, sa usadilo v 260 obciach s väčšinovými obyvatel'mi mad'arskej národnosti, 13 slovenskej a 8 nemeckej. Medzi rokmi 1945 - 1949 približne 125000 obyvatel'ov s mad'arskou národnost'ou opustilo (nútene alebo 
dobrovol'ne) svoje rodné územie. Plán československej vlády o počte presídlených mad'arských obyvatel'ov sa nesplnil, ale realizoval sa plán o horizontálnom a vertikálnom zlome. Pred rokom 1945 ešte jednotné mad’arské etnické územie sa v roku 1950 stalo územím z etnického hl'adiska so zmiešanou populáciou. (Vadkerty 1997, s. 62)

$\mathrm{Na}$ základe porovnania údajov zo sčítania obyvatel'stva v Mad’arsku z roku 1949 s údajmi o bydlisku obyvatel'ov uvedených v sčítaní z roku 1938 sa do Mad’arska presídlilo 90668 obyvatel'ov mad'arskej národnosti z územia Slovenska. Podla mad'arského štatistického úradu počet presídlených tzv. anyás magyarok po roku 1938 bol zhruba 20 tisíc. Štatistici Károly Miltényi a Lajos Thirring počet presídlených Mad’arov (utečenci, vysídlení, deportovaní) odhadli na 130 tisíc. (Stark 2001, s. 409)

\section{Presuny na príklade konkrétnych obcí}

Zámerom československej národnostnej politiky, ako už bolo spomenuté, bolo osídlenie Mad'armi obývaných pohraničných regiónov slovenským obyvatel'stvom, aby Mad’armi obývané vzdialenejšie oblasti zostali odrezané od štátnej hranice a mad’arského etnického územia. Slovákov z Mad’arska plánovali usídlit' v okresoch Šamorín, Dunajská Streda, Komárno, Galanta, Šal'a, Hurbanovo, Štúrovo, Želiezovce, Levice, Šahy, Jesenské, Tornal'a, Moldava nad Bodvou, Král'ovský Chlmec a Vel'ké Kapušany, čiže v 15 okresoch južného Slovenska, obývaných prevažne obyvatel'mi mad’arskej národnosti, ktorých mali presunút' (presídlit') v čo najväčšom počte do Mad'arska.

V juhovýchodnej časti Slovenska vdvoch okresoch (Král'ovský Chlmec, Vel'ké Kapušany) boli vybraté obce na výmenu obyvatel'stva (na presídlenie obyvatel'ov slovenskej národnosti z Mad'arska), kde väčšinu populácie tvorili obyvatelia mad’arskej národnosti. V Medzibodroží mali byt' vysídlení obyvatelia z Král'ovského Chlmca a z obcí v západnej časti regiónu (Borša, Vel'ká Bara, Malá Bara, Černochov, Ladmovce, Viničky, Klin nad Bodrogom, Streda nad Bodrogom, Svätá Mária, Nová Vieska pri Bodrogu, Svätuše), v okrese Vel'ké Kapušany z okresného mesta a obce Budince. (Popély 2009, s. 86-87)

Podla sčítania ludu z roku 1930 sa v okrese Královský Chlmec nachádzalo 33671 obyvatel'ov. Z toho s mad'arskou národnost'ou vykazovali 27600 obyvatel'ov. Slováci tvorili z celkového počtu 5423 osôb. Na území okresu okrem toho žilo obyvatel'stvo s rusínskou národnost'ou (540), v malom počte židia (97) a pol'ská národnost' (11). 
Tabul'ka 1: Výkaz Mad'arov určených na presídlenie z Československa do Mad'arska okres Král'ovský Chlmec

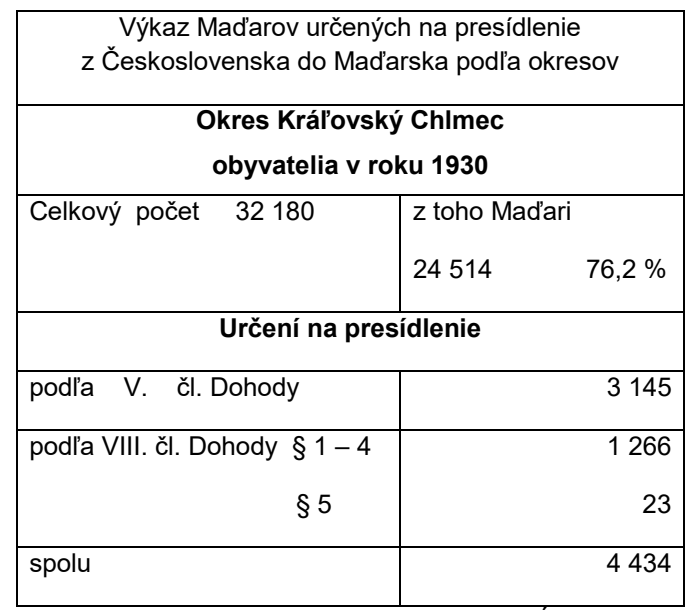

Zdroj: vlastné spracovanie na základe údajov, ktoré publikoval Árpád Popély (Popély 2009, s. 84 )

Podla Árpada Popélya sa vnútorné presídlenie dotklo 17 obcí v nami skúmanom regióne. ${ }^{7}$ Do vybraných obcí presídlili 162 rodín (992 osôb). V najväčšom počte (133 osôb) umiestnili presídlencov v obci Zatín, nasledovala obec Rad (128 osôb), Vel'ký Horeš (125). Viac ako 100 ludí bolo presídlených aj do obce Biel' (103). (Popély 2002)

Tabul'ka 2: Počet presídlených rodín a osôb (optanti, kolonisti, reemigranti, povereníci s rodinami) do jednotlivých obcí v okrese Král'ovský Chlmec k 31.12. 1947

\begin{tabular}{|c|c|c|c|}
\hline \multicolumn{4}{|c|}{ OPTANTI ZO ZAKARPATSKEJ UKRAJINY } \\
\hline Obec & $\begin{array}{l}\text { Počet } \\
\text { rodín }\end{array}$ & $\begin{array}{l}\text { Počet } \\
\text { osôb }\end{array}$ & Pridelené hospodárske jednotky \\
\hline Biel' & 3 & 10 & $\begin{array}{r}1 / 2 \text { hospodárskeho domu, } 10 \text { ha výmera } \\
\text { pôdy } v \text { k.j. }\end{array}$ \\
\hline Bol' & 6 & 15 & 64 katastrálnych jednotiek \\
\hline Bot'any & 11 & 34 & 9 hospodárskych domov \\
\hline Zatín & 41 & 109 & $1661 / 2 \mathrm{ha}$ \\
\hline Rad - Hrušov & 2 & 6 & $11 \mathrm{ha}$ \\
\hline
\end{tabular}

${ }^{7}$ Dané obce v súčasnosti patria do Trebišovského okresu. 


\begin{tabular}{|c|c|c|c|}
\hline Král'ovský Chlmec & 4 & 10 & 1 obytný dom \\
\hline \multicolumn{4}{|c|}{184} \\
\hline \multicolumn{4}{|c|}{ KOLONISTI Z OKRESU KRÁL'OVSKÝ CHLMEC } \\
\hline Biel' & 14 & 52 & 8 hospodárskych domov a 109 ha \\
\hline \multirow[t]{2}{*}{ Bot'any } & \multirow[t]{2}{*}{24} & \multirow[t]{2}{*}{118} & $103 / 4$ hospodárskych domov 89 \\
\hline & & & katastrálnych jednotiek, $991 / 2$ ha \\
\hline Klin nad Bodrogom & 16 & 71 & 144 ha \\
\hline \multirow[t]{2}{*}{ Pribeník } & \multirow[t]{2}{*}{15} & \multirow[t]{2}{*}{61} & 1 hospodársky dom, \\
\hline & & & 188 katastrálnych jednotiek \\
\hline \multirow[t]{3}{*}{ Vel'ký Horeš } & \multirow[t]{3}{*}{7} & \multirow[t]{3}{*}{35} & 4 dom. hosp., 100 katastrálnych jednotiek \\
\hline & & & ornej pôdy; 24 katastrálnych jednotiek \\
\hline & & & pasienkov a 31 ha \\
\hline \multirow{2}{*}{$\begin{array}{l}\text { Streda nad } \\
\text { Bodrogom }\end{array}$} & \multirow[t]{2}{*}{26} & \multirow[t]{2}{*}{133} & \multirow[t]{2}{*}{$41 / 2$ dom. hosp. 204 ha } \\
\hline & & & \\
\hline Rad - Hrušov & 13 & 56 & $921 / 2 \mathrm{ha}$ \\
\hline Vel'ké Trakany & 8 & 29 & 140 ha \\
\hline Král'. Chlmec & 2 & 4 & 10 katastrálnych jednotiek \\
\hline \multicolumn{4}{|c|}{125} \\
\hline \multicolumn{4}{|c|}{ POVERENÍCI ${ }^{1} \vee$ OKRESE V KRÁL'OVSKÝ CHLMEC } \\
\hline Královský Chlmec & 3 & 12 & 3 obytné domy \\
\hline \multicolumn{4}{|c|}{12} \\
\hline \multicolumn{4}{|c|}{ REEMIGRANTI Z MAĎARSKA A JUHOSLÁVIE V OKRESE KRÁL'OVSKÝ CHLMEC } \\
\hline Král'ovský Chlmec & 8 & $15^{2}$ & \\
\hline Borša & 6 & $18^{3}$ & \\
\hline Ladmovce & 1 & 4 & \\
\hline Leles & 1 & 4 & 1 obytný dom pridelila OOÚ \\
\hline Pribeník & 1 & 5 & 1 obytný dom pridelila OOÚ \\
\hline Vel'ký Horeš & 1 & 3 & \\
\hline Malý Horeš & 1 & 2 & \\
\hline & 19 & 51 & \\
\hline
\end{tabular}

Zdroj: vlastné spracovanie na základe archívnych materiálov (Štátny archív v Košiciach, 1948)

${ }^{1}$ Povereníci tvorili špeciálnu skupinu kolonistov, pretože dostali domy, pôdu, pozemky, na ktoré sa nevzt'ahoval konfiškačný zákon a po definitívnej deportácii obyvatel'ov mad'arskej národnosti do Česka sa mali stat' ich majetkom. Od povereníkov sa očakávalo, že budú vernými osobami z národného hladiska a zároveň osobami vhodnými na slovakizáciu v novom prostredí.

${ }^{2}$ z toho 1 osoba z Pol'ska

${ }^{3}$ všetci z Juhoslávie 
Podla mesačných hlásení bolo do konca roka 1947 v obciach okresu Král'ovský Chlmec presídlených 214 rodín (806 osôb). Viac ako polovicu presídlencov tvorili kolonisti (559 osôb), v najväčšom počte (133 osôb) ich umiestnili v obci Streda nad Bodrogom a Bot'any (118). Optantov zo Zakarpatskej Ukrajiny výkazy zaevidovali v Zatíne, išlo o 41 rodín (109 osôb).

Reemigranti tvorili najmenšiu skupinu presídlencov. Do konca roku presídlili len 19 rodín (51 osôb). Do Borše prest’ahovali 18 reemigrantov z Juhoslávie. Jedna rodina prišla z Pol'ska, ostatné rodiny z Mad’arska. Údaje však môžu byt' rozdielne, pretože nie je možné určit' presný počet presunutých obyvatel'ov. Dôvodom môže byt' napríklad nepresnost' výkazov alebo následné presuny presídlencov medzi obcami.

Grafy nachádzajúce sa na nasledujúcich stranách obsahujú údaje o etnickej štruktúre obyvatel'stva vybraných obcí z väčšieho časového úseku, aby bolo možné lepšie zobrazit' dlhodobý dopad. Číselné údaje z posledných sčítaní majú len informatívny charakter.

\section{Bot'any}

Obec Bot’any, v ktorej trvale žije 1256 osôb, leží v juhovýchodnej časti Východoslovenskej nížiny na starom nánosovom vale Tisy $v$ okrese Trebišov, v blízkosti trojhranice - slovenskej, mad’arskej a ukrajinskej štátnej hranice. Počas sčítania obyvatel'ov vykonaného na území prvej Československej republiky v roku 1921 v obci bývali predovšetkým príslušníci mad’arskej národnosti (obr. 1). Vo väčšom počte obyvatelov československej národnosti zaevidovalo sčítanie obyvatel'ov v roku 1930, ked' sa do obce prist'ahovali (1929) v rámci pozemkovej reformy česko-moravskí kolonisti.

Po druhej svetovej vojne sa počet obyvatelov slovenskej národnosti zvýšil vd’aka prist'ahovaným kolonistom v počte 118 . Počet obyvatel'ov slovenskej národnosti doposial' dosiahol najvyššiu hodnotu v roku 2011, 159 osôb (12,7 \%). Popri mad’arských (824 osôb, 56,6 \%) a slovenských obyvatel'och v obci žije aj početná rómska komunita (228 osôb, 18,2 \%). Za svoj materinský jazyk slovenčinu označilo 114 l'udí, čo predstavuje 9,1\% obyvatelov obce. Rómsky jazyk nikto neoznačil za materinský. Vyšší je počet obyvatel'ov s mad'arským materinským jazykom (1094 osôb, 87,1 \%) ako počet obyvatel'ov s mad'arskou národnost'ou (824 osôb, 65,6 \%), z čoho vyplýva, že počet obyvatel'ov so slovenským materinským jazykom bude nižší ako počet obyvatel'ov so slovenskou národnost'ou (114 osôb, 12,7 \%). (Szlovákiai Magyar Adatbank) Kolonisti dokázali zlomit' jednotnú mad’arskú etnickú štruktúru obce, ale ich pomer nikdy nedosiahol $15 \%$ pri sčítaní obyvatel'ov. 


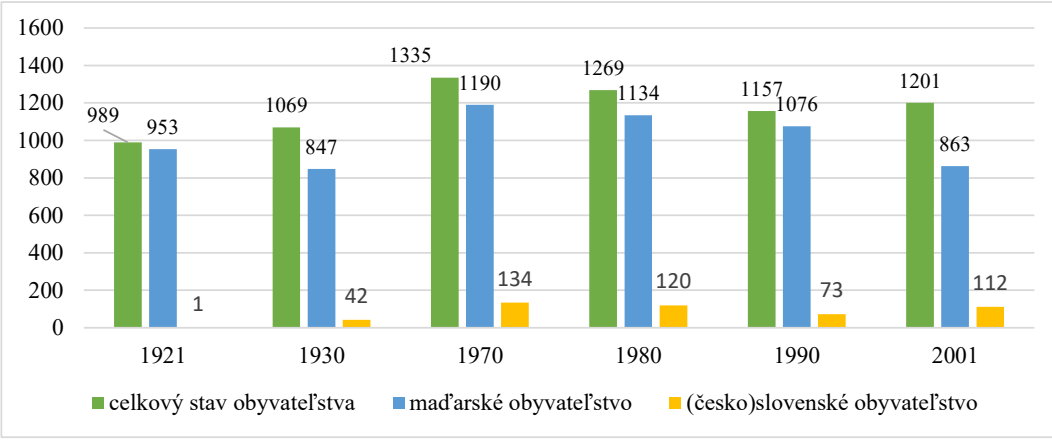

Obrázok 1: Počet obyvatel’ov mad’arskej a (česko)slovenskej národnosti v obci Bot’any

Zdroj: vlastné spracovanie na základe údajov Szlovákiai Magyar Adatbank

\section{Zatín}

Obec sa nachádza v Medzibodroží, severozápade od mesta Královský Chlmec. Sčitanie obyvatel'ov v roku 1921 v obci zaevidovalo 805 obyvatel'ov. Pomer obyvatel'ov mad’arskej národnosti v rámci celkovej populácie bol 95,4 \% (768 osôb). Sčítanie zachytilo 5 $(0,06 \%)$ obyvatel'ov s československou národnost'ou (obr. 2).

Posledné sčítanie obyvatel'ov (2011) zaevidovalo 670 osôb (81,4 \%) mad'arskej národnosti a 122 (14,8 \%) slovenskej národnosti. Za svoj materinský jazyk mad’arčinu označilo 706 obyvatel'ov (85,8 \%) a slovenský jazyk 93 obyvatel'ov (11,3\%). Do obce sa usídlilo po druhej svetovej vojne 109 optantov (41 rodín) zo Zakarpatskej Ukrajiny. Počet obyvatel'ov so slovenskou národnost'ou sa zvyšoval, ale pomer v celkovej populácii vystúpil nad $10 \%$ len od sčítania 2001 (13,8 \%). (Szlovákiai Magyar Adatbank)

Umiestnenie presídlencov, resp. optantov $v$ obci nezlomilo radikálne prevahu mad'arskej národnosti, ale postupne, vel'mi opatrne sa zvýšil počet slovenských obyvatel'ov. 


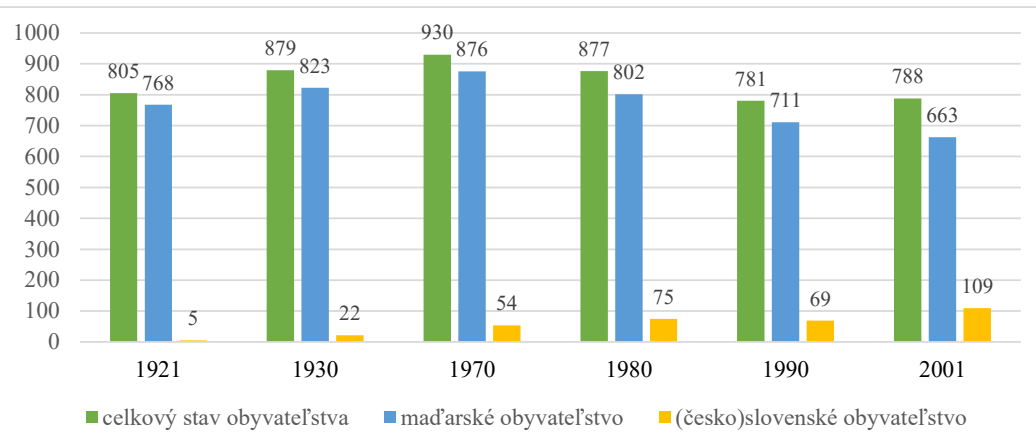

Obrázok 2: Počet obyvatel'ov mad'arskej a (česko)slovenskej národnosti v obci Zatín Zdroj: vlastné spracovanie na základe údajov Szlovákiai Magyar Adatbank

Nie je možne obíst' jeden fakt, ktorý bude bodom d’alšieho výskumu v rámci prípadovej štúdie obce Zatín, načo upozornili vo svojej práci o optantoch aj Marián Gajdoš a Ivan Sjusko, že podl'a dôstojníka Ministerstva obrany ČSR v Košiciach: „vo všetkých transportoch optantov mnohí medzi sebou komunikovali po mad'arsky aj ked' podla opčných dokladov to mali byt' Slováci alebo Česi. Napr. v 13. transporte, ktorý prišiel do pohraničnej stanice Biel 21. júla 1947, štvrtina osôb a v 14. transporte takmer všetci hovorili po mad’arsky. Dôstojník upozornil aj na to, že priezviská osôb nenasvedčujú ich slovenský pôvod." (Gajdoš, Sjusko 1999, s. 29)

Uvedené môže naznačovat', že väčšina optantov umiestnených v Zatíne mohla mat' mad’arskú identitu a pri sčítaniach obyvatel'stva sa už prihlásili k mad'arskej národnosti. Druhý faktor, ktorý tiež mohol zahrat' dôležitú úlohu vo vývoji etnickej štruktúry obce, je odst’ahovanie jednotlivých rodín optantov.

\section{Borša}

Obec leží na pravej strany rieky Bodrog, na západ od Král'ovského Chlmca, pri hranici Slovenska a Mad'arska. Podl'a posledného sčítania z roku 2011 tam žijú obyvatelia s mad'arskou a slovenskou národnost'ou. $\mathrm{K}$ mad'arskej národnosti $\mathrm{z}$ celkovej populácie sa prihlásilo 545 osôb (44,9 \%), k slovenskej 644 (53,0 \%). Za materinský jazyk označilo mad'arčinu 777 osôb $(64,0 \%$ ) a slovenčinu 414 (34,1\%). Z obyvatel'ov obce v roku 1921 na základe sčitania obyvatel'ov skoro 90 \% malo mad'arskú národnost' (749 osôb, 88,0 \%). Len 7,5 \% obyvatel'ov sa prihlásilo k slovenskej národnosti t.j. 64 osôb. 010 rokov neskôr podiel slovenskej národnosti sa zvýšil na 16,7 \%, o 40 rokov až na 52,2 \% (obr. 3). (Szlovákiai Magyar Adatbank) 
Výmena obyvatel'stva, vnútorné presídlenie a stým spojený asimilačný proces jednoznačne zmenili etnický charakter obce. Po druhej svetovej vojne čast' obyvatel'ov s mad’arskou národnost'ou presídlili do Mad'arska, namiesto nich prišli presídlenci so slovenskou národnost'ou, napr. aj z bývalej Juhoslávie.

Borša patrí medzi tie obce, kde migračné pohyby dokázali zmenit' etnický charakter. Počas jednotlivých sčítaní obyvatel'ov sa striedala prevaha mad’arského a slovenského obyvatel'stva. Pri sčítaní obyvatel'stva v rokoch 2001 a 2011 sa ale pomer obyvatel'ov mad'arskej a slovenskej národnosti takmer vyrovnal.

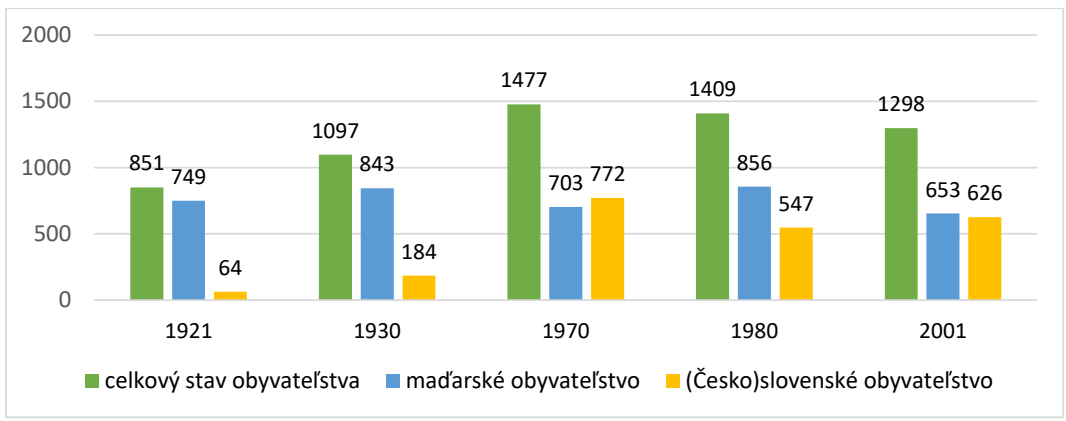

Obrázok 3: Počet obyvatel’ov mad'arskej a (česko)slovenskej národnosti v obci Borša Zdroj: vlastné spracovanie na základe údajov Szlovákiai Magyar Adatbank

\section{Streda nad Bodrogom}

Obec Streda nad Bodrogom leží na l'avej strane rieky Bodrog, v blízkosti mad’arskej a slovenskej štátnej hranice. Tiež patrí medzi tie obce, kde migračné pohyby (kolonizácia v rámci pozemkovej reformy, výmena obyvatel'ov medzi ČSR a Mad’arskom), reslovakizácia a asimilácia ovplyvnili etnický charakter. Podla sčítania obyvatel'ov z roku 2011 v obci prevažuje mad'arská národnost'. V súčasnosti v obci žijú Rómovia, Rusíni, Česi, Ukrajinci, Poliaci, Nemci, Chorváti a značná čast' obyvatel'ov neuviedla národnost'. Z celkovej populácie 2239 osôb má mad'arskú národnost' 1216 (54,3 \%) a slovenskú 842 (37,6 \%) osôb. Rozdiel medzi slovenským materinským jazykom a slovenskou národnostou je výrazný. Len polovica obyvatel'ov so slovenskou národnost'ou označila za svoj materinský jazyk slovenčinu (488 osôb, 21,8 \%). Prvé oficiálne sčítanie ČSR z roku 1921 zaevidovalo z celkovej populácie obce 1516 osôb mad'arskej národnosti $(90,4 \%$ ). K slovenskej národnosti sa hlásilo 62 obyvatelov obce $(3,7 \%)$. V roku 1930 počet obyvatelov so slovenskou identitou značne zvýšil a počet obyvatel'ov s mad'arskou národnost'ou sa znízil (obr. 4). Čo ovplyvnilo približne 400 obyvatel'ov, aby v priebehu 10 rokov zmenili národnú identitu? Politický vývoj, strach o rodinu, 
majetok, zamestnanie, existencia ovplyvnili prihlásenie sa $\mathrm{k}$ tej-ktorej národnosti počas sčítania v roku 1941, ktoré bolo vykonané mad’arskými úradmi 3 roky po pripojení obce k Mad’arsku (1938). Z celkovej populácie sa k slovenskej národnosti prihlásilo len 7 ludí. Po druhej svetovej vojne sa obec stala znova súčastou Československa. Počet obyvatelov slovenskou národnost'ou vobdobí 1970 - 1980 rapídne vzrástol. (Szlovákiai Magyar Adatbank) Obec Streda nad Bodrom bola silne postihnutá vyššie spomenutými procesmi, ktoré dokázali vyvolat' zmeny v etnickej štruktúre.

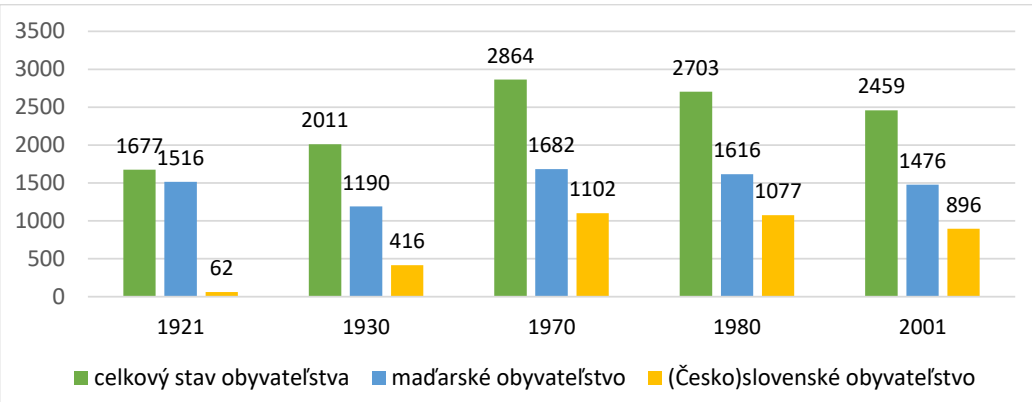

Obrázok 4: Počet obyvatel'ov mad'arskej a (česko)slovenskej národnosti v obci Streda nad Bodrogom

Zdroj : vlastné spracovanie na základe údajov Szlovákiai Magyar Adatbank

\section{Záver}

Po druhej svetovej vojne štáty bojovali s hospodárskou krízou, krajiny boli zničené a život l'udí bol zat’ažený navyše ešte aj rôznymi presunmi. Utečenci, vyhnanci, ludia nútení opustit' svoje domovy hl'adali útočisko a silu začat' odznova budovat' svoju existenciu. Historici venujúci sa podrobne danej problematike jednoznačne konštatujú, že presídlenie obyvatel'ov mad'arskej národnosti do Mad'arska ako aj vnútorný presun obyvatel'ov mal tragický dopad na mad’arskú menšinu: rozbitie z etnického hladiska jednotného územia na juhu Slovenska, zmena etnickej štruktúry, presuny $v$ pomeroch celkovej populácie medzi obyvatel'mi slovenskej a mad'arskej národnosti v jednotlivých obciach, mestách, konfiškácia pozemkov, domov, a navyše aj psychická trauma, ktorú museli prežit počas a po presídlení. Pre jednoduchého človeka to bola z psychologického ako aj sociologického hladiska vel'mi náročná a t’ažká fáza. Osudy l'udí, ktorí sa stali súčast'ou mechanických pohybov je vhodnejšie skúmat' na lokálnej úrovni, kde sa môžu vykryštalizovat' špeciálne procesy a udalosti, ktoré zasiahli nielen do života jedinca ale celej obecnej komunity. Daný vývoj sa mohol odlišovat' od všeobecných konštatovaní. Súčasná historiografia sa problematike mechanického pohybu 
venuje viac z politického a hospodárskeho hladiska. Kým jednotlivé vzájomne sa ovplyvňujúce faktory, udalosti nebudú dôkladne prebádané aj na lokálnej úrovni, dovtedy predsudky najmä potomkov dotknutých strán budú bolestivé a živé. Práca teda otvorila d’alšie otázky, ktoré bude potrebné v budúcnosti preskúmat' a následne publikovat' prípadové štúdie. Ide napr. o to, aké faktory ovplyvnili etnický vývoj obcí, čo bolo špecifické v asimilačnom procese, ako to prežívali ludia $v$ jednotlivých obciach, aké boli reakcie obyvatel'stva na tieto zmeny. Predložená práca poslúži ako základný materiál pre d’alší výskum na regionálnej úrovni a prípadové štúdie o jednotlivých obciach.

Štúdia vznikla v rámci riešenia projektu VEGA č. 1/0316/19 Výmena obyvatel'stva medzi Československom a Mad'arskom - fakty a historické súvislosti v domácej a európskej politike.

\section{Archívne materiály}

Štátny archív v Košiciach, fond Oblastná úradovňa Osídlovacie úradu v Král'ovskom Chlmci, Rôzne zápisnice 1946 - 1948, Spisy z roku 1948, inv. č. 20, š. 3. Nominálne výkazy osídlených uchádzačov domácich a reemigrantov podla obcí a okresov a mesačné hlásenia predložené Osídlovaciemu úradu pre Slovensko, stav k 31.12.1947.

\section{Literatúra}

GAJDOŠ, M., SJUSKO, I. 1999. Optácia obyvatel'ov Zakarpatska v československosovietskych vzt'ahoch v rokoch 1945 - 1947. In: Clovek a spoločnost', roč. 2, č. 3, s. 27-34, ISSN 1335-3608. [cit. 4-6-2021]. Dostupné na internete: http://www.clovekaspolocnost.sk/jquery/pdf.php?gui=TWT6TUB34SFJTUY7BYIIDLUSV\&fbcl id=IwAR3cvc3wb_07uC9hUHcf3hRizphJLsQJ1aos-OdHdacNSTx3q3tQkQYeTyg

POPÉLY, Á. 2002. A második világháború utáni belső telepítések Dél-Szlovákiában. In: Fórum Társadalomtudományi Szemle, roč. 6, č. 3, ISSN 1335-4361. [cit. 16-8-2021]. Dostupné na internete:

http://forumszemle.eu/2002/06/07/popely-arpad-a-masodik-vilaghaboru-utani-belsotelepitesek-del-szlovakiaban/

POPÉLY, Á. 2009. Výmena obyvatel'stva medzi Československom a Mad’arskom a menné zoznamy Mad'arov určených na presídlenie. In: Človek a spoločnost', roč. 12, č. 1, s. 79-93, ISSN 1335-3608. [cit. 21-6-2021]. Dostupné na internete: http://www.clovekaspolocnost.sk/jquery/pdf.php?gui=A44B5F6279ZJERRFMWMXA735X

ROMSICS, I. 2000. Az újraosztott köztes-Európa. A térség szovjet uralom alá kerülése 1945 után. In: Európai utas. Az európai együttmüködés folyóirata, roč. 11, č. 38, s. 6-15, ISSN 0866$272 X$.

SÁPOSOVÁ, Z. 2019. Presídlenie Slovákov z Mad’arska do Československa (propagačná činnost' Československej presídl'ovacej komisie a st'ažnosti slovenských presídlencov počas výmeny obyvatel'stva). In Človek a spoločnost', roč. 22, Supplement, s. 75- 91, ISSN 1335- 
3608. [cit. 2-6-2021]. Dostupné na internete: http://www.clovekaspolocnost.sk/UserFiles/article/files/156343866806-saposova.pdf

SIMON, A. 2004. Deportálás. [cit. 25-9-2021]. Dostupné na internete: https://adatbank.sk/lexikon/deportalas/

STARK, T. 2001. Háborús népességmozgás a Kárpát-medencében (1938-1948). In: FARAGÓ, T., Öri, P. (eds.). A központi Statisztikai Hivatal Népességtudományi Kutatóintézetének 2001. évi történeti demográfiai évkönyve. Budapest: Központi Statisztikai Hivatal, s. 389-411, ISBN 9637109838.

SZARKA, L. 2007. A csehszlovák-magyar lakosságcsere helye a magyar kisebbség tervezett felszámolásában 1945-1948 között. In: Kisebbségkutatás, roč. 16, č. 3, s. 415-430, ISSN 1215-2684.

Szlovákiai Magyar Adatbank. [cit. 30-7-2021]. Dostupné na internete: https://adatbank.sk/

ŠUTAJ, Š. 1993. Mad'arská menšina na Slovensku v rokoch 1945 - 1948. Bratislava : Veda, ISBN 80-224-0209-5.

ŠUTAJ, Š. 2013. Rokovania o mieri s Mad'arskom a ich vplyv na postavenie mad'arskej menšiny na Slovensku. In: Asta Universitatis Carolinae luridica, roč. 59, č. 1, s. 277-298, ISSN 0323-0619. [cit. 24-8-2021]. Dostupné na internete: https://karolinum.cz/data/clanek/624/luridica_1_2013_23_Sutaj.pdf

VADKERTY, K. 1996. A deportálások. A szlovákiai magyarok csehországi kényszerközmunkája 1945-1948 között. Pozsony: Kalligram, ISBN 8071491519. [cit. 15-52021]. Dostupné na internete: https://adatbank.transindex.ro/html/alcim_pdf12075.pdf

VADKERTY, K. 1997. A belső telepítés Szlovákiában (1945-1949). In: Irodalmi Szemle, roč. 40 , č. 6-7, s. 58-64, ISSN 1336-5088.

VADKERTY, K. 2004. Reslovakizáció. [cit. 25-9-2021]. Dostupné na internete: https://adatbank.sk/lexikon/reszlovakizacio/

VADKERTY, K. 2007. A belsõ telepítés Szlovákiában (1945-1949). In: MOLNÁR, I., SZARKA, L. (eds.). Otthontalan emlékezet. Emlékkönyv a csehszlovák-magyar lakosságcsere 60 . évfordulójára. Komárom: MTA Kisebbségkutató Intézet, s. 42-47, ISBN 978-963-06-2513-5. [cit. 2-9-2021]. Dostupné na internete: https://kisebbsegkutato.tk.hu/uploads/files/archive/245.pdf

VADKERTY, K. 2014. A csehszlovákiai magyarok felszámolásának terve és gyakorlata 19451948 között. In: RABI, L. (ed). „MAĎARI ZA DUNAJ!” Felvidéki magyarok kitelepitése és deportálása 1945-1948 között. Szöveggyüjtemény a korszak tanulmányozásához. Kecskés László Társaság, ISBN 978-963-88929-2-8. [cit. 16-7-2021]. Dostupné na internete: http://www.klt.hu/docs/felvideki_magyarok_kitelepitese.pdf 


\section{Adresa autorov}

Mgr. Zlatica Sáposová, PhD.

Centrum spoločenských a psychologických vied SAV

Spoločenskovedný ústav

Karpatská 5

04001 Košice

E-mail: saposova@saske.sk

Mgr. Miroslava Gallová, PhD.

Centrum spoločenských a psychologických vied SAV

Spoločenskovedný ústav

Karpatská 5

04001 Košice

E-mail: gallova@saske.sk 